\title{
Potentials for Public Private Partnerships for Saudi Municipalities
}

\author{
Waleed Abdullah Abdulaal \\ Department of Urban and Regional Planning, Faculty of Environmental \\ Design, King Abdulaziz University, Jeddah, Saudi Arabia
}

(Received: 4/02/2006, Accepted: 25/02/2007)

\begin{abstract}
Public Private Partnership (PPP) provides an approach for improving the efficiency of public services. Municipalities in Saudi Arabia are encouraged to get into arrangements with the private sector to improve their service delivery. However, existing practices in municipal services are confined to outsourcing and no attempt has been made towards PPP. This paper aims at examining the potentials for PPP in providing municipal services. The paper starts by reviewing a theoretical background to establish a general framework for PPP. Hence, the decision of municipalities to partner with a private stakeholder is a key resolution to municipalities; the paper defines the circumstances that make it a feasible decision to test their applicability to Saudi municipalities. Particular referencing is given to Jeddah city due to difficulties in getting data on municipal services in general which can be overcome by personal knowledge and experience. In this case, author's knowledge about the city of Jeddah gathered from his post as a Deputy Mayor provides a descriptive source for the research which follows an explorative approach. The main findings of the paper include that most municipal services suffer from inadequate resources and that they are dominated by a low quality of delivery. Municipalities are therefore recommended to prepare a strategic framework that considers PPP to improve their services. However, PPP may not be a good alternative for all services; rather it can be a potential recourse for improving public work projects currently run through conventional procurement.
\end{abstract}

Keywords: Public Private Partnership, Municipal services, Urban management, Saudi Arabia. 


\section{Introduction}

Municipalities in Saudi Arabia perform varying services that include urban planning, public works, and environmental services together with other groups of services. Although municipalities attempted outsourcing as an approach to improve efficiency in delivering services, public private partnership (PPP) has not yet been applied for municipal services. Municipalities are always under public pressure to provide services in a better way than they are. Effectiveness of service delivery requires overcoming serious problems such as deficient business processes and inadequate public finance to cope up with growing public demands. There is a growing perception in Saudi Arabia towards giving the private sector more roles in service delivery. Therefore, the purpose of this paper is to explore the potentials for PPP for municipal services.

The paper starts by providing a theoretical review of PPP specially its definition, features, types, and applications which is covered in section 2. It is found that PPP is usually instigated by the public partner to satisfy certain conditions. Accordingly the decision to partner becomes a vital stage in progressing with PPP as discussed in section 2. This decision depends on the maturing of certain circumstances that if reached will make PPP more feasible for the public body to pursue in its effort to improve service delivery. The theoretical underpinning as presented in section 2 provides a general framework for the analysis of PPP potentials in Saudi Arabia, which becomes the focus of the remaining of the paper that starts by reviewing existing legislation and government policy towards PPP as handled in section 3. Further the study examines the existing framework for delivering municipal services as presented in section 4. Analysis of the ripping circumstances for PPP of municipal services is reviewed in Section 5.

The paper concludes in Section 6 that while it is important to improve municipal service delivery and that PPP presents an option towards achieving this end, municipalities need to develop a clear strategy in this regard. Focus in this research is given to the Municipality of Jeddah due to limited references on municipal service delivery in general. Further, there is no reason that makes service delivery in Jeddah departs from that of other cities and towns in Saudi Arabia, as all municipalities follow incomparable administrative structure, responsible for delivering similar services and abide to a unique legislative system. Author's knowledge on Jeddah gained from his post as a Deputy Mayor for Services and then as a Deputy Mayor for Construction and Projects 
contributed to the focus on Jeddah. The researcher background as a senior municipal official acquainted him to understand the context within which Saudi municipal systems work. Therefore, collecting knowledge for this research is not looked to employing usual teqneeques such as questionnaires and interviews, but mainly by being directly engaged in managing and directing municipal affairs. Accordingly the researcher was able to build a reasonable account of knowledge and observations which are used for judging and elaborating municipal issues related to Jeddah.

\section{Theoretical Background}

\subsection{Definition}

There are different phrases that define $\operatorname{PPP}^{[1-4]}$, but all are indifferent in admitting that PPP refers to contractual agreement between public and private sector partners to:

"renovate, construct, operate, maintain and/ or manage a facility or system in whole or in part, that provides a public service. Under these arrangements, the agency may retain ownership of the public facility or system, but the party generally invests its own capital to design and develop the properties ${ }^{[1]}$, p. 1 .

The characteristics of such partnership involve the sharing of investment, risk, duties and benefits between the partners. However, responsibilities of the public sector always stem from the fact that the public sector is the guardian of community interests and therefore, local authorities and municipalities remain responsible and accountable for delivering public services in a way that protects and maintains people's interests. In the contrary, private partners are motivated by profit making. Accordingly, successful partnerships strike a balance between the varying aims of each sector to provide a service or a project in an effective and efficient way by building the basis for useful integration of the assets of everybody ${ }^{[1]}$.

However, such definition may fit other activities including privatization $^{[5]}$. To distinguish PPP from other forms of public private engagement, Thomson stressed that a PPP should (i) be instigated by the public sector, (ii) include a precise project definition, (iii) emphasize risk sharing between both parties, (iv) be bound by contractual arrangements with a defined time frame, and (v) present an apparent distinction between public sector and the borrower ${ }^{[5]}$. The justification for such partnership is derived from the unique features of each sector (public and 
private) buildings on the merits possessed by each sector in particular areas of service or project delivery. Therefore, partnership aims at amalgamating robust strengths of both sectors in particular arrangements to establish reciprocal liaison ${ }^{[6]}$. In general, PPPs are usually formulated to outperform limitations of traditional public procurement for providing public services. To a great extent, PPPs play a major role in bridging the gap between growing investment needs for public services and limited public resources ${ }^{[2,7,8,9]}$. Other reasons include the realization of cost reduction, increased efficiency and effectiveness which can be achieved through the bundling of tasks that makes one party (private partner) in charge of all stages of the production chain ${ }^{[10]}$. In summary, under conventional procurement, the public authority defines the inputs and holds to control rights over the method of service delivery. Instead under PPP, the government stipulates outputs and standards associated with the public service, but the private partner is given control rights over how to deliver the service ${ }^{[11]}$.

Public private partnership can vary in terms of the degree of risk associated with each partner, skills and expertise possessed by each collaborator and the potential implications for citizens. In mixed economies there is a wide range of arrangements available for Public Private Partnership, which can intermit in scale and risk. Each type of participation is characterized by special features associated with certain advantages and disadvantages, which have to be considered deeply by local authorities, to choose the most suitable type that meets their needs (Table 1). The essential input among all these types is the degree of private participation in delivering public services that ranges from operation and maintenance to full development as in BOT projects. The varied tools of PPP provide different contexts that put private sectors merits in finance, technical skills, innovations, efficient managerial schemes and entrepreneurial sprit together with public knowledge and assets $^{[12]}$. Characteristics of the various forms of PPP including their application, advantages and disadvantages are summarized in Table 2. A common advantage to most types of Public Private Partnership is the increased efficiency, seconded by cost savings which are difficult to achieve through government bureaucracy. In contrast, municipalities will be under-privileged by reduced owner control through majority of partnerships. Moreover, it is clear from Table 2 that most applications of the assorted forms of public / private partnerships are associated with infrastructure services, while other municipal services such as environmental health, land and property, planning and zoning, etc. seem 
to have little attention. Therefore, there is room for innovative ideas to incorporate private partners in such fields.

Table 1. Types of Public Private Partnerships.

\begin{tabular}{|c|c|c|}
\hline No. & Type of PPP & Description \\
\hline 1 & $\begin{array}{c}\text { Operations and } \\
\text { Maintenance } \\
\end{array}$ & $\begin{array}{l}\text { The local government contracts with a private partner to operate and } \\
\text { maintain a publicly owned facility. }\end{array}$ \\
\hline 2 & Design-Build & $\begin{array}{l}\text { The local government contracts with a private partner to design and } \\
\text { build a facility that conforms to the standards and performance } \\
\text { requirements of the local government. Once the facility has been built, } \\
\text { the local government takes ownership and is responsible for the } \\
\text { operation of the facility. }\end{array}$ \\
\hline 3 & $\begin{array}{l}\text { Turnkey } \\
\text { Operation }\end{array}$ & $\begin{array}{l}\text { The local government provides the financing for the project but engages } \\
\text { a private partner to design, construct and operate the facility for a } \\
\text { specified period of time. Performance objectives are established by the } \\
\text { public sector and the public partner maintains ownership of the facility. }\end{array}$ \\
\hline 4 & $\begin{array}{l}\text { Wrap Around } \\
\text { Addition }\end{array}$ & $\begin{array}{l}\text { A private partner finances and construct an addition to an existing public } \\
\text { facility. The private partner may then operate the addition to the facility for a } \\
\text { specified period of time or until the partner recovers the investment plus a } \\
\text { reasonable return on investment. }\end{array}$ \\
\hline 5 & Lease-Purchase & $\begin{array}{l}\text { The local government contracts with the private partner to design, } \\
\text { finance and build a facility to provide a public service. The private } \\
\text { partner then leases the facility to the local government. This approach } \\
\text { can be taken where local government requires a new facility or service } \\
\text { but many not be in a position to provide financing. }\end{array}$ \\
\hline 6 & $\begin{array}{l}\text { Temporary- } \\
\text { Privatization }\end{array}$ & $\begin{array}{l}\text { Ownership of an existing public facility is transferred to a private } \\
\text { partner who improves and/or expands the facility. The facility is then } \\
\text { owned and operated by the private partner for a period specified in a } \\
\text { contract or until the partner has recovered the investment plus a } \\
\text { reasonable return. }\end{array}$ \\
\hline 7 & \begin{tabular}{l|} 
Lease- \\
Develop- \\
Operate or \\
Buy-Develop- \\
Operate \\
\end{tabular} & $\begin{array}{l}\text { The private partner leases or buys a facility from the local government, } \\
\text { expands or modernizes it, then operates the facility under a contract with } \\
\text { the local government. The private partner is expected to invest in facility } \\
\text { expansion or improvement and is given a specified period of time in } \\
\text { which to recover the investment and realize a return. }\end{array}$ \\
\hline 8 & $\begin{array}{l}\text { Build-Transfer- } \\
\text { Operate }\end{array}$ & $\begin{array}{l}\text { The local government contracts with a private partner to finance and build a } \\
\text { facility. Once completed, the private partner transfers ownership of the } \\
\text { facility to the local government. The local government then leases the } \\
\text { facility back to the private partner under a long-term lease during which the } \\
\text { private partner has an opportunity to recover its investment and a reasonable } \\
\text { rate of return. }\end{array}$ \\
\hline 9 & $\begin{array}{c}\text { Build-Own- } \\
\text { Operate- } \\
\text { Transfer }\end{array}$ & $\begin{array}{l}\text { The private developer obtains exclusive franchise to finance, build, } \\
\text { operate, maintain, mange and collect user fees for a fixed period to } \\
\text { amortize investment. At the end of the franchise, title reverts to a public } \\
\text { authority. }\end{array}$ \\
\hline 10 & $\begin{array}{l}\text { Build-Own- } \\
\text { Operate }\end{array}$ & $\begin{array}{l}\text { The local government either transfers ownership and responsibility for } \\
\text { an existing facility or contracts with a private partner to build, own and } \\
\text { operate a new facility in perpetuity. The private partner generally } \\
\text { provides the financing. }\end{array}$ \\
\hline
\end{tabular}

Source: Ministry of Municipal Affairs ${ }^{[6]}$, pp. 7-10. 


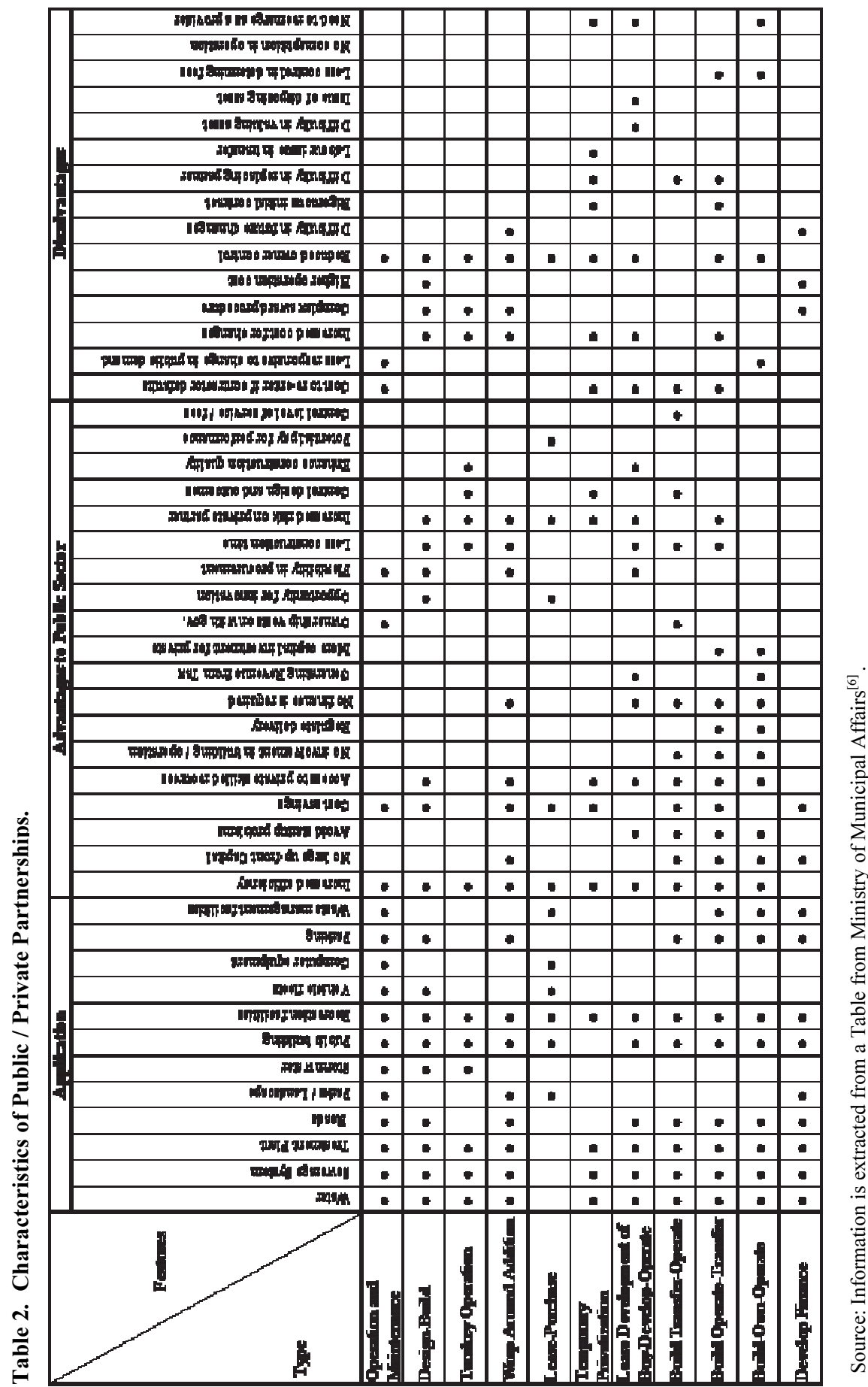




\subsection{The Decision to Partner}

In fact, the decision to partner with a private stakeholder is a critical conclusion for a local authority or municipality that has to decide on the appropriate form for the delivery of a certain service or project. Meanwhile, PPP may not be the best option for providing a public service. Because, PPP can provide benefits over traditional procurement in terms of economic efficiency, but such betterments carry some costs that may or may not outbalance the gains ${ }^{[13]}$. Therefore, a local authority or municipality should follow a careful method, and analyze all relevant factors and issues to choose the fit type of association. Accordingly, the key question for a local government or a municipality is when to partner with private sector? There are certain circumstances, when reached, justify the decision to associate with a private partner (Table 3). Once circumstances are mature for partnership, a local government or municipality must move forward to cover certain issues, by following subsequent steps as illustrated in Fig. 1. The whole approach runs in a cycle initiated, firstly, by riping circumstances, where the local authority is certain that it is in a status favoring partnerships. Once confidence is built upon the local authorities or municipality, then it shall work on the second step to develop the business and legal framework for association. This becomes the backbone for the forthcoming partnership. Third, is to define / select the proper approach for partnership. Section 2.1 reviewed the most common forms of partnership, which may be increased by more innovative forms that suit certain needs. Forth step focuses on setting the legitimate arrangements associated with the selected approach, which shall be put to implementation as requested in the fifth step. Monitoring is the final stage that feeds back to circumstances to accommodate for any changing or arising positions to be amalgamated in the process.

The rest of this paper converges on applying this framework to the Saudi case. It starts by shedding light on the policy and legal framework for municipal partnership, to pave the way for reviewing the existing framework for delivering municipal services.

\section{Policy and Legislation}

The Saudi government undertook a long running effort to enhance performance of municipalities through various measures, including organization improvements, increased funds, opening citizen 
participation and focusing on citizens' demands. In fact, the Seventh Development Plan (2000-2004) aimed at providing basic necessities to improve living and environmental standards in cities, to continue completing municipal services and enhance their economic and performance efficiency and effectiveness. In addition, the Plan encouraged privatizations for certain municipal services ${ }^{[15]}$. Privatization here is used in its wider context, that includes public / private partnership, out-sourcing and outright privatization. The call for privatization was also reiterated by the Council of Ministers in 2003 by resolution No. 219, which approved privatization of certain utilities and services including some municipal services ${ }^{[16]}$.

Table 3. Factors Affecting the Decision of a Local Authority to Partner with a Private Stakeholder.

\begin{tabular}{|c|c|}
\hline Attribute & Description \\
\hline Inadequate Finance & $\begin{array}{l}\text { The service or project cannot be provided with the financial resources } \\
\text { or expertise of the local government. }\end{array}$ \\
\hline $\begin{array}{l}\text { Low Quality of } \\
\text { Service }\end{array}$ & $\begin{array}{l}\text { A private partner would increase the quality or level of service from } \\
\text { that which the local government could provide on its own. }\end{array}$ \\
\hline Time Saving & $\begin{array}{l}\text { A private partner allows the service or project to be implemented } \\
\text { sooner than if only the local government was involved. }\end{array}$ \\
\hline Use Support & $\begin{array}{l}\text { There is support from the users of the service for the involvement of a } \\
\text { private partner. }\end{array}$ \\
\hline Competition & $\begin{array}{l}\text { There is an opportunity for competition among prospective private } \\
\text { partners. }\end{array}$ \\
\hline $\begin{array}{l}\text { No Legal } \\
\text { Prohibitions }\end{array}$ & $\begin{array}{l}\text { There are no regulatory or legislative prohibitions to involving a } \\
\text { private partner in the provision of service or project. }\end{array}$ \\
\hline $\begin{array}{l}\text { Measurable } \\
\text { Outcomes }\end{array}$ & The output of the service can be measured and priced easily. \\
\hline Cost Recovery & $\begin{array}{l}\text { The cost of the services or project can be recovered through the } \\
\text { implementation of users' fees. }\end{array}$ \\
\hline Innovative & The project or service provides an opportunity for innovation. \\
\hline Track Record & $\begin{array}{l}\text { There is a track record of partnerships between local government and } \\
\text { the private sector. }\end{array}$ \\
\hline $\begin{array}{l}\text { Economic } \\
\text { Development }\end{array}$ & There are opportunities to foster economic development. \\
\hline
\end{tabular}

Source: Description of attributes is quoted from Ministry of Municipal Affairs, $1999^{[6]}$, p. 18. 


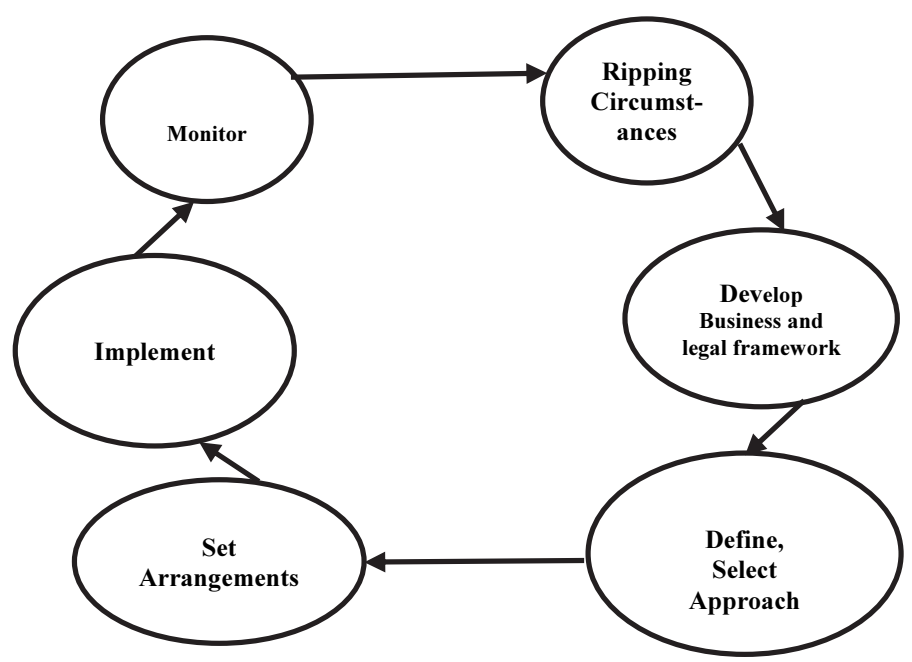

Fig. 1. Conceptual framework for municipal partnership. Source: After (OPDM, 2004 ${ }^{[14]}$, p. 22)

It is worthy noting that most privatization efforts within municipal perspective are confined to outsourcing. The Ministry of Municipal and Rural Affairs (MOMRA) commissioned a study about privatizing municipal services which recommended a list of more than 30 municipal services that can be privatized. Initiatives for privatization started in a few municipalities, for example, outsourcing vehicles supply to the Municipality of Jeddah, and collection of municipal revenues in Buraidah. In addition, there are few services which were privatized, such as city cleansing and pest control, but still there is a long list of municipal services which are deployed by municipalities.

Government support and orientation towards privatization and strive to encourage public/private partnership faced difficulties. There are some legislative obstacles, related to assigning fees for services, which are provided with no charge on beneficiaries. These legislative obstacles become more serious, when faced with the widely accepted view by the society, that considers public services, including municipal services, are state responsibility, and citizens resent any increase or addition to existing fees or charges. Another difficulty comes from the fact that knowledge on partnership needs to be addressed to municipalities to expand the scope upon which municipal enterprise can work. Municipalities should be acquainted with the available measures that they can use, to improve the quality of services within the circumference of 
limited resources. The knowledge base about partnership is not readily attainable in a way that municipalities can make use of to direct their actions. However, the enthusiasm towards outsourcing and privatization required new legal provision to organize and facilitate their existence. Though there has been some development in legal codes, the existing legislation does not knuckle down to all legal aspects for adopting necessary partnership types.

So far, existing legislative provisions constraint many of the opportunities for municipalities to enter into arrangements of partnership, to provide or manage a facility or work for them. Amendments to existing legislation shall ease constraints on partnership. However, lack of legal provisions on partnership does not deter municipalities from taking initiatives to request changes and improvements. The most pressing need is to expand the knowledge base on PPP's definition, measures, usefulness, and best practices available locally, in neighboring countries and elsewhere.

\section{Existing Framework for Delivering Municipal Services}

Municipalities in Saudi Arabia deliver a wide range of services covering various fields, as stipulated in The Law of Municipalities and Villages ${ }^{[17]}$. Specifically The Law empowered municipalities to plan, organize and control urban growth and development. Moreover, The Low enabled municipal authorities to provide certain utilities, manage municipal assets, control and monitor environmental health and premises together with other city activities and internal municipal functions, such as finance and administration. In practice, these municipal duties interrelate with other city functions performed by other local public agencies such as infrastructure, transportation, housing and social services (Fig. 2). Given that the city is a system of interrelated parts, therefore, performance of municipal services requires municipalities to coordinate and work with other public agencies to harmonize their activities. Further more, enforcement of municipal bylaws calls for police powers especially in cases that are difficult to accomplish by municipal staff. By the same token, public bodies responsible for providing and managing other city services such as water and sewerage networks, provision of electricity, mosques, schools, health care, sports and protective services are adherent to city plans prepared by municipalities.. 
The framework for delivering such expansive province of varied services includes several elements namely; functions and specialty, nature of service, beneficiaries, cost recovery and method of delivery. These factors are discussed bellow.

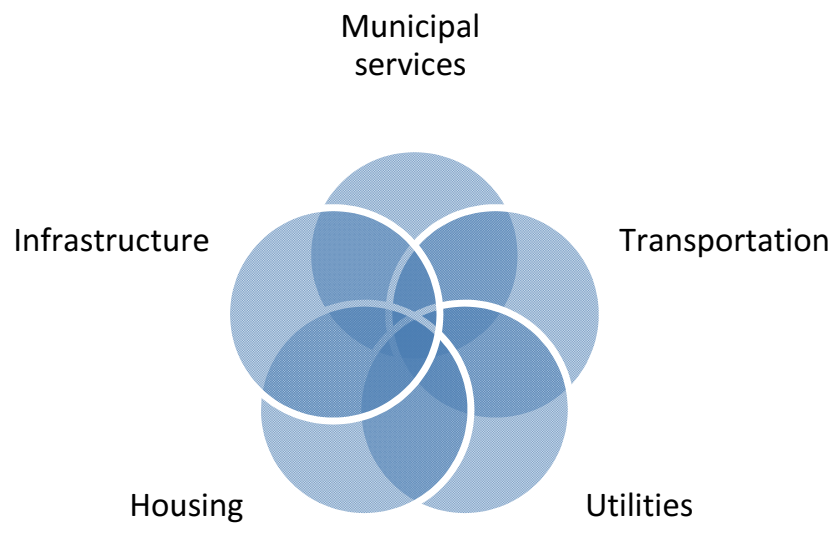

Fig. 2. Municipal services and other city services.

\subsection{Functions and Specialty}

Municipalities are requested to meat various needs of community that affect the environment that they live, work, socialize and recreate on. Such broad scope of required services demands some sort of specialty to care for the extensive expertise and skills deemed necessary to handle service delivery. The wide range of services normally requires ample functions that are associated differently by the diversified services delivered by municipalities as illustrated in Fig. 3. Broadly speaking, municipal services can be categorized into ten groups, according to their main stream specialty which covers; planning and development control, public works, land and property, environmental health and premises, aesthetics, calls and operations, social and cultural services (cemeteries, municipal museums and festivals only), investment (municipal assets), finance and administration, and information related services. Specifically, the most influential municipal service is urban planning and development control that eventually empowers municipalities to regulate location, intensity, and use of all developments within their jurisdiction. Accordingly, it is indubitable to find out that planning and development control counts for the largest proportion $18 \%$ of all the 66 municipal 
services (Fig. 3). Equally important are services agnate to environmental health and premises control, which are among the main duties of municipalities which cover $15 \%$ of the total number of municipal services. In fact, municipalities are in charge of certain public works that include; roads, pavements, street lighting, parking and public parks, all of which mount to $14 \%$ of municipal services. Other groups of municipal services cover fewer proportions of municipal services, as they become more focused to specific businesses. For example, municipal duties towards land and property (contain $11 \%$ of the entire services carried out by municipalities) centre around specific services associated with land grants and management of municipal land, where land registry is handled by Ministry of Justices. In contrast, controlling aesthetic values of the city is a prime responsibility of municipalities, which is practically adopted in association with other controls, such as planning and environmental health. Therefore, aesthetic services cover only $5 \%$ of the entire municipal services.

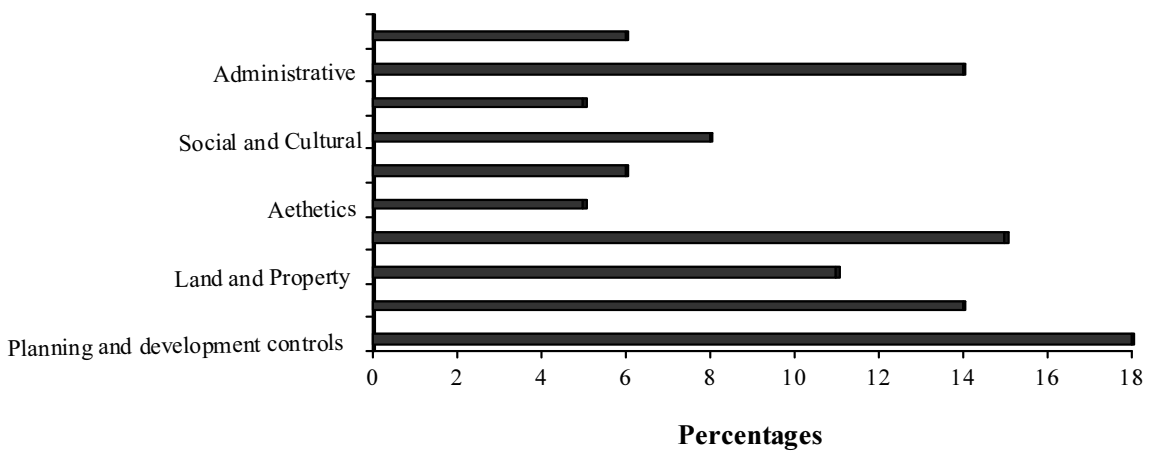

Fig. 3. Distribution of municipal services.

Grouping of municipal services goes in line with municipal structure that, divides a municipality to distinctive departments which consummate appropriate services ${ }^{[18]}$. Service delivery maintains very low duality among municipal departments, but there is ample evidence of interrelationships among municipal departments in handling one service. For example, public works are accomplished largely by two departments namely, Study and Supervision, and Maintenance and Operation. The former focuses on new constructions while the latter is concerned with operation and maintenance of existing facilities and newly built amenities. Further dichotomy is apparent in handling land related services carried out by Departments of Urban Planning and Land and 
Property, with some involvement by Surveying Department. For example, Land Subdivision Plans for land grants are prepared by Urban Planning Department, delineated by Surveying Department, and distributed to grantees by Land and Property Department. This significant appropriateness, in handling service delivery, contributes to specialized working procedures, which are crippled by bureaucracies associated with public organizations.

\subsection{Nature of Services}

Municipalities provide services of different natures which can be categorized as construction, maintenance and operation, providing information, control, guidance and organizational as illustrated in Table 4 and Fig. 4, together with other characteristics. Municipal services that involve construction refer to building of projects for drainage systems, roads, side walks, and other municipal works, all of which mount to the lowest proportion (14\%) of all municipal services. That is to say municipalities are not the only provider of infrastructure and utilities in Saudi cities. In fact, the provision of infrastructure and utilities is fragmented among different agencies, for example water and sewage networks are undertaken by the Water and Sewage Authority, while water is supplied by Desalination Plant Authority. In contrast to construction, operation and maintenance services run by municipalities extend over the largest proportion (41\% of services conducted by municipalities) and usually refer to the management and functioning of developed assets, and other ongoing city services, such as waste management, pest control, swamp clearance, cemeteries etc. Provision of information reflects the valuable data available within municipal authorities, who can be helpful and perhaps necessary for businesses and public decisions. Municipalities can provide information through one third $(32 \%)$ of its extended services. Involvements of municipalities in city planning and development control, in addition to other controls qualify them to become data rich. Subsequently, municipalities maintain a significant role in building urban, environmental, socio-economic and demographic data about their jurisdictions. Guidance of development is applied by the municipality in its capacity as an organizer and a planner of urban development, in addition to few other activities, therefore covering a relatively lower proportion $(20 \%)$ of municipal functions. In contrast, services that bear control nature affiliated with the responsibility of municipal authority as a major guardian of public interests within their 
localities especially in land development and environmental health, which incorporate a proportionately high segment $(36 \%)$ of all municipal businesses. Organizational services invoke methodological disposal of administrative and structural arrangements within municipal systems, which are typified by a small share $(17 \%)$ of all businesses run by municipalities as presented in Table 4 and Fig. 4.

It is worthy to note that in a few instances, there is no clear cut line for the nature of certain services because one service may take in more than one character. For example, local planning provides information, prescribes control and gives guidance for development. Furthermore, the nature of most public works related services combines construction with operation and maintenance.

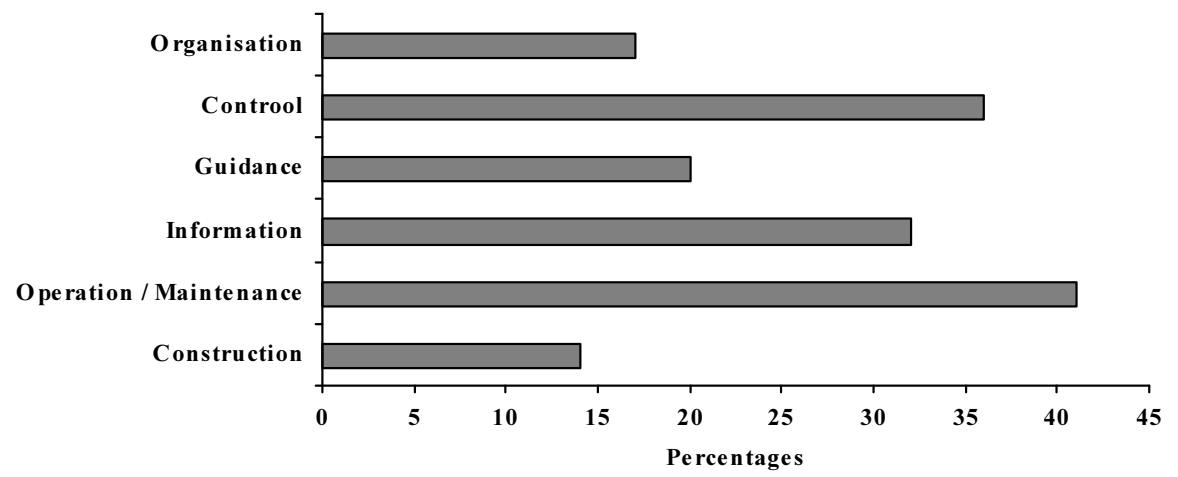

Fig. 4. Nature of municipal services.

Source: Table 4.

\subsection{Beneficiaries}

Recipients of municipal services can fall into four categories, namely; general public, businesses, public bodies, and/or municipal departments. A service may be provided to more than one category of recipients which may include two groups of recipients as noted by Parks and Landscaping, which benefit the general public and businesses that may rent out up to $10 \%$ of public parks to invest on activities provided to park users. Some services care for all types of recipients, as evidently noticed by some of the planning and development controls (Table 4 and Fig. 5). However, the general public benefit from the largest proportion $(74 \%)$ of municipal services, which stems from the role of municipalities as a public service provider. Businesses are advantaged by less significant portion ( $55 \%$ ) of municipal services. Meanwhile, municipal 


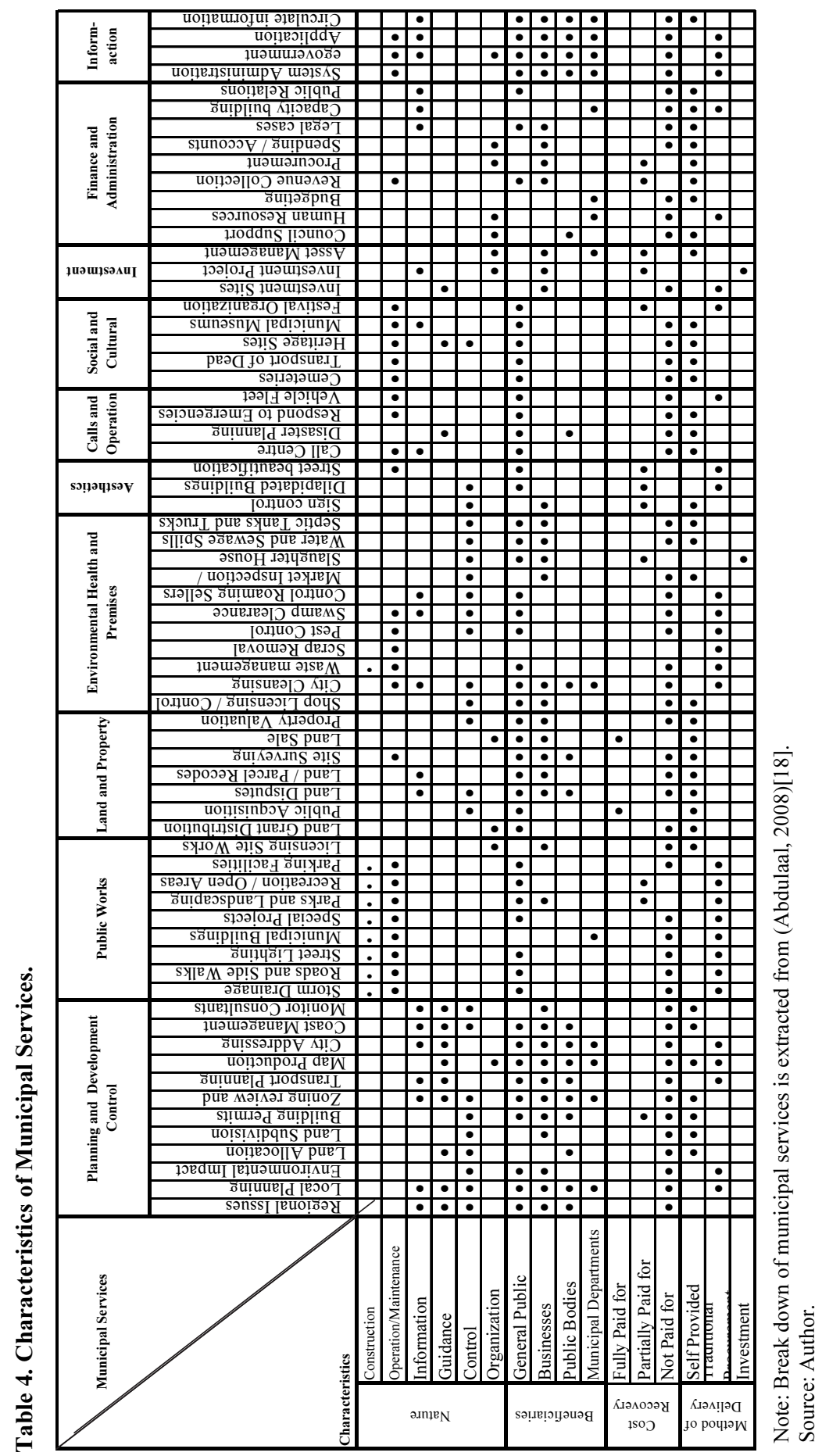


services that contribute to business operations account for more than double the services profited by public bodies (27\%), or municipal departments $(21 \%)$ as illustrated in Table 4 and Fig. 5. Although, municipalities provide services to public and municipal departments, their main role is to extend city services to the general public and concerned businesses. This character in itself put municipalities accountable to their main recipients i.e. city dwellers. Although, residents can complain about quality of service, municipalities are not directly accountable to the general public because municipal authority does not involve public participation in an effective way. Positively speaking, the revived municipal councils in late 2004, that include half elected members, are expected to assume an effective role in this regard. In practice, accountability of municipal authorities is recognized against municipal adherence to administrative and financial rules and regulations, but not aimed towards service quality. Accordingly, effectiveness of existing delivery of municipal services is not measured and does not lead to a constructive approach of improvement.

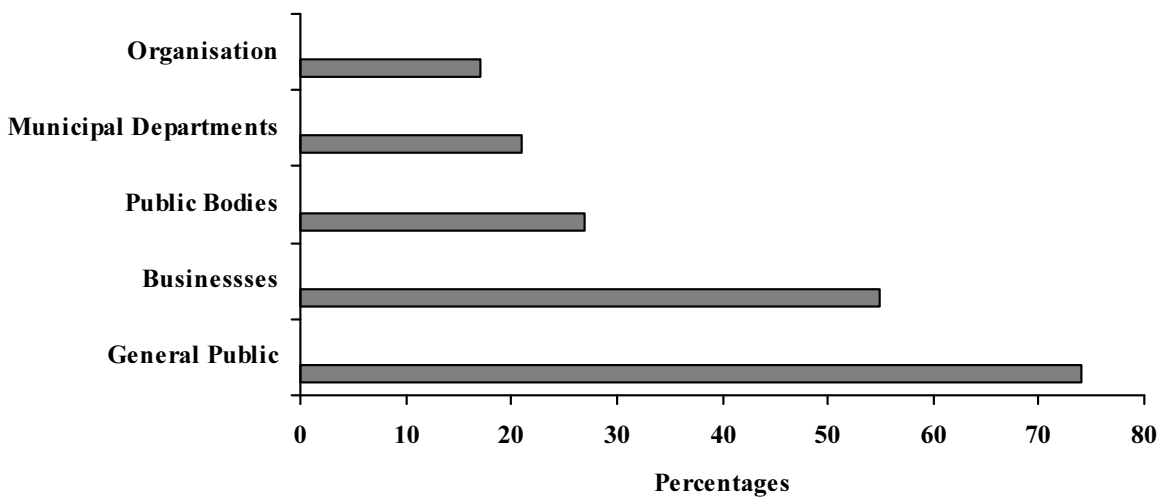

Fig. 5. Benefeciariers from municipal services.

Source: Table 4.

\subsection{Cost Recovery}

Municipal income depends largely on central budget, while municipal returns are limited to collection of revenues generated by limited land sale, fees on shop licenses, sign controls, lease of municipal properties, and penalties. Municipalities do not levy any sort of tax. Land lease provided a major source for the Municipality of Jeddah for the years 2004 and 2005, while other sources of municipal income fluctuated 
along the same period except for income from advert signs which remained nearly stable (Fig. 6). Although revenue of the Municipality of Jeddah increased by 15\% between 2004 and 2005, municipal revenue usually doesn't exceed $20 \%$ of municipal budget, while the remaining fund is allocated from national budget. This heavy reliance on central funds increases central controls over local matters conducted by municipalities. Table 4 and Fig. 6 show that most municipal services $(79 \%)$ are not paid for, while only $3 \%$ of services are fully paid fore and $18 \%$ of municipal services are partially paid for. The current service delivery is characterized by minimal cost recoveries that limits municipal revenues and therefore jeopardizes municipalities in meeting growing needs for services. In practice, the decision to increase municipal expenditure rests primarily on central support initially raised through negotiations between municipalities with Ministry of Municipal and Rural Affairs (MOMRA) which is finally settled with Ministry of Finance. It is worthy noting that municipal revenue, though limited, form a significant resource to fund part of the cost paid for municipal services that are characterized by an operation and maintenance nature which cover $41 \%$ of all municipal services (Fig. 7). Nationally, municipal revenues compasses $52 \%$ of money spent on municipal operation and maintenance which mounts to $19.2 \%$ of all the budget of MOMRA ${ }^{[20]}$. The fact that most of the municipal services are funded by state and provided for free for the residents is stemmed from welfare state that Saudi Arabia enjoys. It is widely believed within Saudi society that state is responsible to provide municipal services with little or even no cost on the public. This widely accepted view hinders municipal initiatives to introduce new charges or to increase existing ones.

Therefore, municipalities find themselves in tight position as they are in one hand, under pressure from the public to improve their service delivery, and on the other hand they depend largely on central funds to meet public demands. However, it is worth noting that the majority of municipal services is typified as public goods which are characterized by non-excludability in consumption, because once services are provided individual consumers can not be distinguished in using or making use of them, and that usage by one individual does not reduce usage possibilities for others ${ }^{[13]}$. Accordingly, it becomes difficult to put defined charges on some services with wide public usage. 


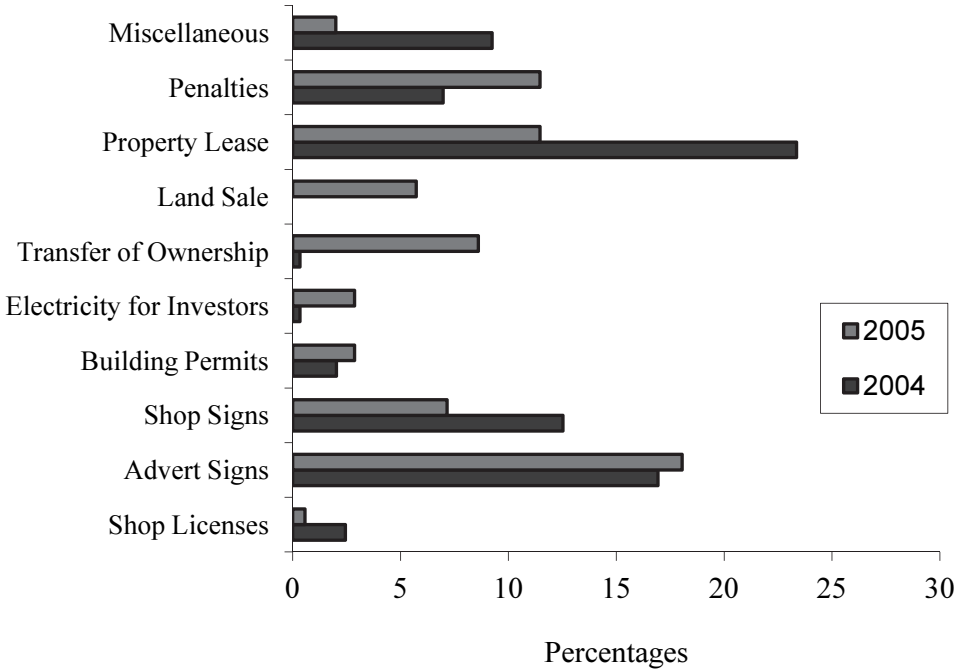

Fig. 6. Revenues of the municipality of Jeddah.

Source: Municipality of Jeddah, Budget Report [19].

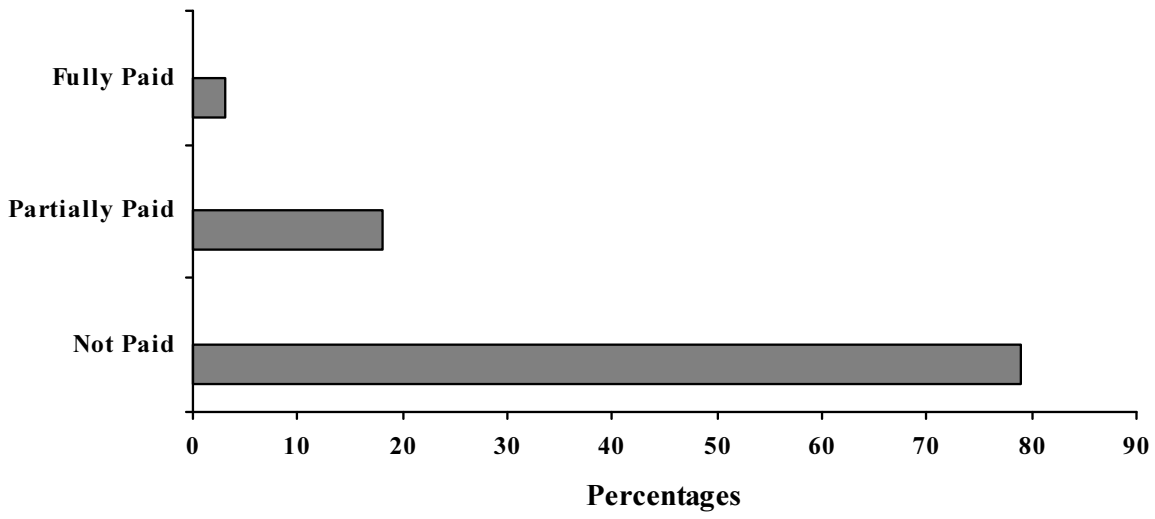

Fig. 7. Cast recovery for municipal services.

Source: Table 4.

In general, collection of municipal revenue is a big burden on municipalities. MOMRA initiated a programme to outsource the collection of municipal revenues purposely to increase the efficiency of the collection process and to alleviate pressure on municipal authorities to encourage them focusing on prime functions. In 2005 Jeddah Municipality entered into an agreement with a private consultant to collect municipal revenues, yet progress on this initiative has always been fraught with difficulties. 


\subsection{Method of Delivery}

Municipalities in Saudi Arabia have limited choices towards the method of delivery of their services. The majority of municipal services $(56 \%)$ is self provided by municipal departments; especially services prevailed by control and provision of information (Table 4 and Fig. 8). By contrast $42 \%$ of municipal services are outsourced to specialized contractors through conventional procurement methods, while the remaining $2 \%$ of municipal services is provided through investment projects i.e. municipality let out land or property to investors to provide certain services. Generally speaking, conventional procurement is disadvantaged by assigning risks like construction overruns, and high maintenance $\operatorname{cost}^{[7]}$. Although these risks are partially transferred to private contractors in outsourcing methods, yet most municipal contracts lack the ability to handle complete service delivery by private contractor, therefore hinder the transferring of risks to the private contractors, or even not able to reach to a rational risk sharing between the municipality and the private contractor. Accordingly, existing outsourcing is incapacitated to allocate risk to who can manage it in a better way be it the municipality or the private contractor which consequently, affect the efficiency of outsourced services.

\section{The Ripping Circumstances}

The decision to go for partnership forms a departure point that entails the concerned municipality to evaluate situations of service delivery to judge the real costs and benefits associated with partnership. Section two outlined the benefits and risks accompanying partnership and specified eleven criteria to examine circumstances that may call for partnership. This section attempts to test the ripping circumstances for introducing PPP for municipal services in Jeddah. Judgment on status connected to each of the 66 services provided by municipalities depends on overall assessment supported by author's experience as a Deputy Mayor for services and then for Construction and Projects in the city of Jeddah. This assessment is underpinned by evidences connected to some selected services. Table 5 and Fig. 9 present an analytical account of circumstances associated with municipal services which is discussed below. 


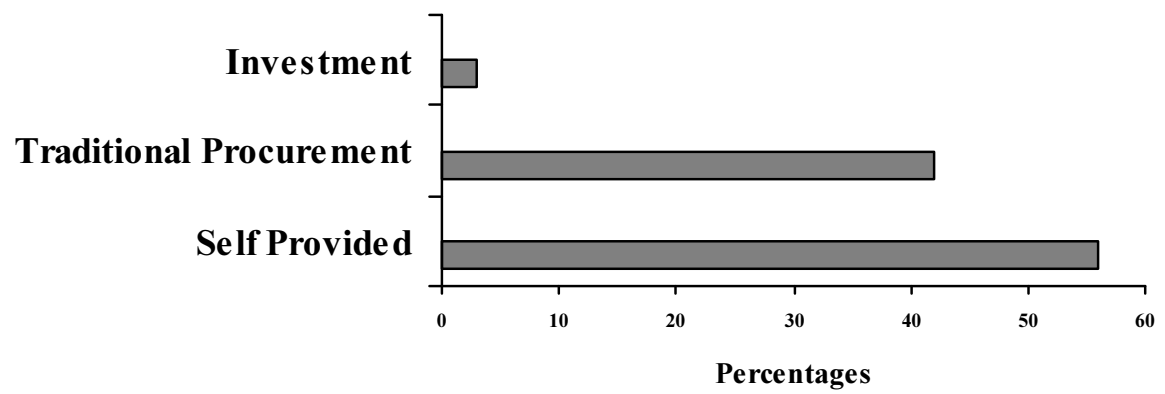

Fig. 8. Method of delivery for municipal services.

Source: Table 4.

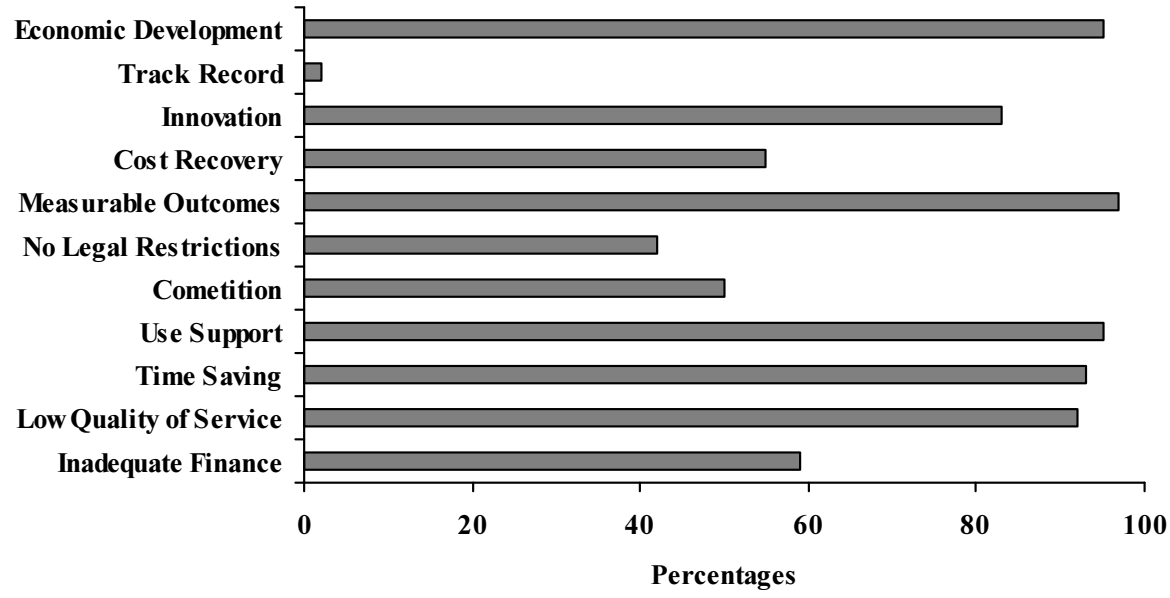

Fig. 9. Status of municipal services.

Source: Table 5 .

\subsection{Inadequate Finance}

Availability of finance is a key challenge that faces most municipalities; hence they largely depend on central capital. It is found that $59 \%$ of municipal services are affected by inadequate finance and resources (Fig. 9), not only because of limited central fund but also in coping with rapid urban growth, which expands the area over which service delivery stretches. In fact, the city of Jeddah expanded from 367 $\mathrm{km}^{2}$ in 1987 to $4977 \mathrm{~km}^{2}$ in $2004^{[21]}$. In contrast, money allocated for service delivery is not growing at the same pace. For example, money allocated for cleaning Jeddah between 2002 and 2007 was 420 million Riyals, where the city cleansing needed double what was allocated ${ }^{[22]}$. Accordingly, city cleansing was contracted to a private operator, within 
budget limitations, that resulted in a low quality service which forced the municipality later to struggle for additional funds.

\subsection{Quality of Services}

Hence, a large segment of municipal services is adversely affected, by inadequate finance as discussed in section 4.4. Accordingly, it is not surprising to find out that the majority $(92 \%)$ of municipal services suffers from deficient conditions (Table 5 and Fig. 9). This considerable proportion characterized by shoddy service quality reflects the high demand from the public for better service delivery. Although opinion studies on municipal services are not available and rarely attempted, polls run through the web site of the municipality of Jeddah during 2007 showed that $82 \%$ of respondents were dissatisfied with growth of Jeddah, while only $10 \%$ expressed their satisfaction and the remaining $8 \%$ were very content ${ }^{[23]}$. Local press are always critical towards municipal services, all evidences though not scientifically recorded lead to the pressing public demand for more appropriate municipal services. This can be expressed strongly by the newly established semi-elected municipal councils, which institutionalized public involvement in municipal affairs. Generally, low service quality is not limited to selfprovided services by municipalities, but also include outsourced services. Reasons for, dominant low quality of services should not be attributed to limited financial resources alone, but must be viewed as a result of the existing improper framework for service delivery as discussed in section 4. The existing practice is not self correcting, and is not subject to performance management, and therefore, is not motivated towards improving outcomes. More understanding for the declined quality of municipal services can be reached by discussing the following situations associated with service delivery.

\subsection{Time Saving}

City services are further disadvantaged by lengthy time associate with service delivery, where $93 \%$ of municipal services need to achieve time savings (Table 5 and Fig. 9). This major portion of municipal services is carried out either by municipal staff or contracted to a second party, through conventional procurement. The Municipality of Jeddah is understaffed, therefore, adversely affecting the quality of services delegated to municipal staff. Unfortunately, low qualities of services 


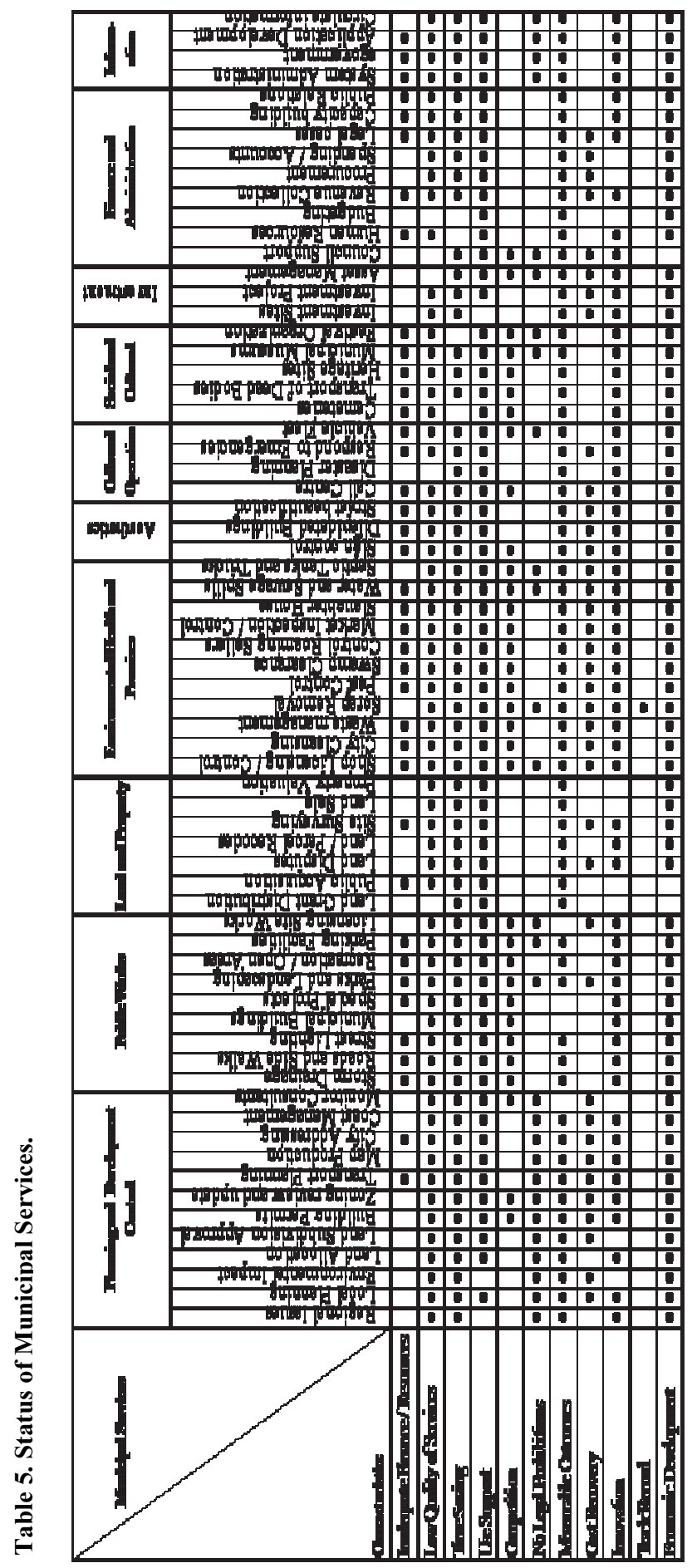


processed by municipal workers are further demoted by the shortage of qualified personnel, ineffective procedures and the limited use of IT applications. Services implemented through traditional procurement are underperformed due to (i) budgetary limitations, (ii) the conventional procurement process favors lower bids regardless of their expected outcomes, due to the focus on unassuming inputs, (iii) unpretentious project management carried out by municipal staff, while private businesses are achieving important cost and time savings by improving their process and moving towards internet services, municipalities are lagging behind with very slow development in transaction processing depriving their institutions from reduced processing costs, and efficient inventory management, (iv) limitations inherent to the traditional procurement approach that do not favor bundling of all stages of service delivery to one party, therefore do not attempt to reduce cost through the life cycle of project or service ${ }^{[10]}$.

\subsection{Use Support}

Along the same grounds, municipalities require use support in service delivery which is spotted for $95 \%$ of municipal services (Table 5 and Fig. 9). The main reason is the limitation of human resources in quantitative and quantitative grounds. Number of skilled staff in The Municipality of Jeddah is not increasing on the same pace as service delivery requires. For example, the number of inspectors needed to cover the growing number of premises in the city is quadrant the existing number ${ }^{[24]}$. The same scenario applies to many services. The problem of staffing is compounded by the lack of standards that define the ratios of staff / population deemed necessary for reasonable service delivery.

\subsection{Competition}

Competition among service delivery is limited, due to the bulk of services provided by municipal staff. Municipal services are not oriented towards market based competition, due to the wide spread believe that municipal services are not commercial in nature and not paid for. However, advantages of competition can be realized, once municipal services delivery is not locked to existing municipal practices.

\subsection{Legal Prohibitions}

Legal framework associated with public private partnership was discussed in section 3 and pinpointed the problems connected to the 
obstruction of existing legislation towards partnership which is so far limited to outsourcing, through operation and maintenance. Constraints to other forms of public private partnership shall be removed by the enactment of new provisions. In fact, legislation forms the back bone for any system to operate, but once there is a clear wide variation between operations of businesses and public agencies, that lead to incomparable outcomes, therefore legislation shall be responsive to cope with changing circumstances and advancements in continually / growing businesses and technologies. Accordingly, legal basis for more than half of municipal services need to be reviewed to give municipal authorities some mandate to consider private partners in their service delivery (Table 5 and Fig. 9).

\subsection{Measurable Outcomes}

The characteristics of municipal services reviewed in section 4 suggest that service qualities can be evaluated and therefore, their outcomes can be measured. However, most municipal staff believes that their outcomes cannot be measured as they don't employ indicators that suit service quality. So far, municipalities' performance is not judged against measurable outcomes for service delivery. This does not mean that measurable indicators cannot be developed. The Municipality of Jeddah finished in 2005 a detailed review of its procedures and performance efficiency, as part of its aim to qualify for ISO 9000. Structured methods and approaches can be developed to weigh the presence of a reliable database that can produce a resourceful centre for most municipal data. So far, existing spending and resource allocation approaches are not linked to performance or outcomes, though municipalities depend largely on central funds which can be rationalized by directing municipalities to produce effective results. Measurable outcomes are essential to assess municipal performance to determine the value and success of service delivery. Given the nature of municipal services discussed in section 4, it can be concluded that the preponderance of municipal services $(97 \%)$ is able to have measurable outcomes (Table 5 and Fig. 9).

\subsection{Cost Recovery}

Cost recovery is an important issue to all municipalities, the dominance enjoyment of the public by the widespread conception of continued free service delivery lead to further pressure on municipalities, to improve service delivery with incapacitated resources, which cannot 
be realized. In theory, $55 \%$ of municipal services can appreciate cost recovery from beneficiaries, if legislation is relaxed (Table 5 and Fig. 9). It is hoped that the newly animated municipal councils (2005) will look seriously to this issue, and strive to take necessary actions to enact new provisions that help municipalities to obtain cost recovery for services delivered by them. However, the move towards bringing in new charges to unpaid services or to increase the amount of existing ones will not be welcomed by the general public as they add on the people's financial commitments. Nevertheless, one may argue that putting municipal authority before public accountability may ease reluctance of the public towards charging issues which can be particularly achieved by seriously inviting the public to some sort of participation in municipal affairs.

\subsection{Innovation}

Rapid technological advancements especially in communication and information require municipalities to be innovative to cope with developments elsewhere. However, practically speaking, it is not difficult to feel the big gap between public and private agencies in modernization and use of technology. In general, public bodies including municipalities are slow in coping with technological advancements because their performance is not subject to well known criteria and not geared towards improving outcomes. Therefore, it is assumed that not less than $83 \%$ of municipal services strive for innovative approaches in their delivery (Table 5 and Fig. 9). Limitations within municipal resources coupled with low encouraging working environment within municipalities jeopardize the realization of innovations by municipalities alone.

\subsection{Track Record}

Track record of Public Private Partnership in municipal service delivery is minimal and confined to services carried out through operation and maintenance method. Knowledge base conjoined to public private partnerships is very bound. In contrast, there is quite ample record to outsourcing through conventional procurement as shown in section 4.5. Two decades ago, outsourcing was a new concept and had barely limited records, now it has built a long record, though not satisfying acceptable level of service delivery. The lack of track record to PPPs for municipal services in Saudi Arabia must not stop municipalities from applying what proved to be successful elsewhere, as far as PPP presents a potential contribution for better service delivery of certain city services. 


\subsection{Economic Development}

Finally, economic development can be fostered by the improvement of service delivery through appropriate methods. Although no studies have been undertaken to establish the effect of the quality of municipal services on local economy and their role in economic development, it is believed that $95 \%$ of municipal services will bring immediate advantages to the local economy if their quality is enhanced (Table 5 and Fig. 9). All the disadvantages associated with municipal services discussed above encourage this believe. Because most weaknesses of municipal service delivery contribute negatively to efficiency and effectiveness of municipal systems in administering and providing public services which is part of the local economy.

\section{The Need for PPP Strategy}

In general the above analysis indicates that ripping circumstances are in favor of the move towards PPP for most services, but legislative barriers have to be removed to pave the way for municipalities to develop and apply solutions for their service delivery, especially overcoming the limitations of public finance. Equally relevant is the issue of cost recovery, because progression towards PPP approach will require the private sector to realize revenue from users. This will call for a change in legislative provisions to allow for cost recovery that may not gain an immediate public support. However, in the long run cost recovery can gain public backing by the potential improvement in service delivery and progressive public participation in municipal decisions, which allows for transparent accountability. Considering the two important characteristics of PPP, i.e., the bundling of service delivery stages in one, and private ownership that guarantees sharing of risk and benefits between public and private partners ${ }^{[10]}$, the question is whether PPP model is an appropriate alternative for all municipal services or not. Notwithstanding the potentials of PPP to overcome certain shortcomings of traditional procurement, especially economic efficiency and budget constraints, PPP may not provide the best alternative to improve all municipal services, especially for services that involve public controls against market forces and resisting private interests. PPP can provide a good alternative to conventional procurement of public work projects. Because, public work projects usually require upfront capital expenditures and satisfy PPP 
main features i.e., bundling and private ownership. However, public works related services include $13 \%$ of municipal services, and the remaining majority of city services would require alternative approaches for improvement. Therefore, municipalities have to determine their priorities towards PPP within a clear strategy to improve their services. Certainly the strategy should give serious consideration to solve the inadequacy in public finance within an existing framework that does not charge for services.

In this regard, municipalities are requested to consider their core activities that are sensitive to be delegated to private partners such as municipal controls over urban development, environmental health and other city affairs. Therefore, municipal authorities must distinguish between services that require intensive public involvement and conduct from those services that are less susceptible to this dictum. Figure 10 attempts to provide a perspective towards elaborating how municipal services can be arranged into significant and less significant core municipal activities. Significant core municipal services are those that are dominated by public controls and guidance which take the centre of the circular shapes that represent municipal enterprise. Activities become less significant to core municipal services, as they distance themselves from the centre, evidently seen in construction and maintenance, which are currently outsourced to private contractors through conventional procurement. Peripheral activities are more appropriate to enter into PPP engagements especially for capital projects. In contrast PPP becomes less feasible for services close to the centre, mainly because of the absence of track records in this regard neither locally nor regionally, in addition to the concern of delegating public power to private partners. Therefore, improvement strategy for municipal service delivery based on PPP can develop gradually building on success stories on easy areas for application. In this strategy, priority should be given to none core municipal activities such as the construction of public work projects, meanwhile core services must find reliable methods for immediate improvement, for example, calling for technical support, re-engineering business procedures, and modernizing working environments which can be achieved by consultations with professional private offices. Activities that are in between core and peripheral services such as organization and information are less sensitive to remain totally within municipal domain, 
and accordingly can benefit from outsourcing in preparation for appropriate PPP engagement.

However, municipalities must expand their knowledge base to find the fit approaches that solve their internal shortcomings and problems associated with the delivery of their varied services. Accordingly, the proposed approaches to improve service delivery for core and non core activities need to be put for further studies, to come up with practical solutions to municipalities.

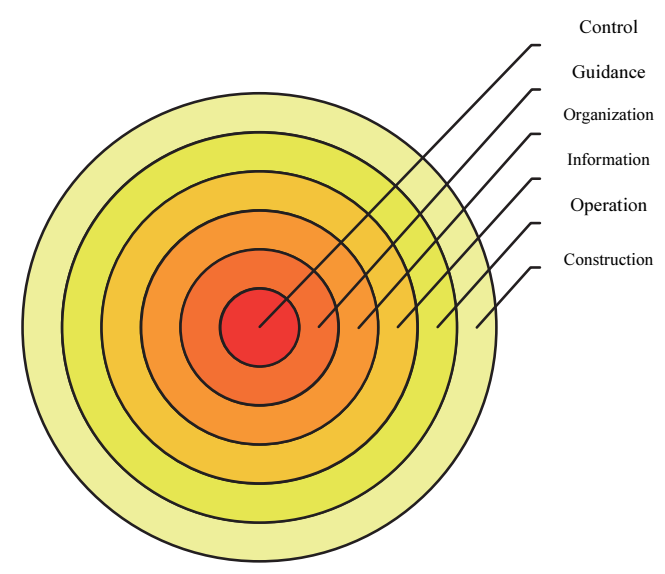

Fig. 10. Core and none core municipal activities.

\section{Conclusion}

Public Private Partnership provides an approach to overcome problems of traditional procurement, and there are different types of PPP that encompass different advantages and disadvantages. In general, PPP involves grouping of different activities that include construction, maintenance and operation of services in one agreement with a private partner that shares risk and benefits with public partner through the principle of private ownership of related asset. Municipalities in Saudi Arabia are engaged in wide ranging services. The forgoing discussions reviewed existing framework of municipal service delivery with particular reference to Jeddah, and concluded that services can be grouped under ten subjects with varying characteristics, particularly in their nature that can be overwhelmed by one or more features such as construction, operation and maintenance, information, guidance, control and/or organization. Municipal services are largely oriented towards the 
general public and businesses at no cost for the overwhelming proportion of services. Existing methods of delivery do not incorporate any form of PPP. While $56 \%$ of municipal services are self provided by municipalities themselves, $42 \%$ is outsourced to private operators through traditional procurement. In general, revision of existing situation of municipal services with particular reference to Jeddah showed serious drawbacks in the existing service delivery, that include inadequate finance and low quality services together with other negative features. Accordingly, there is a genuine call for improving municipal services.

There are some legislative barriers towards the move for PPP as an approach for improving municipal services. However, the predominant deficiency in the quality of municipal service delivery, that encompass the self provided and outsourced services, alike entails municipalities to develop an improvement strategy that considers PPP as one of the possible approaches to overcome existing deficiencies especially for public works services that encompass construction, maintenance and operation. Building an improvement strategy for municipal services requires municipalities to move gradually towards PPP programmes while differentiating between core and none core activities, so that municipal authorities are able to choose the right approach for improvement. Further research is recommended to expand the knowledge base of municipalities to provide them with practical approaches and procedures to develop and implement their strategy on improving service delivery.

\section{References}

[1] Smithson, J., "Public-Private Partnership Definition", at: http://www.klamathbucketbrigade.org/ Publicprivatepartnership061004.htm, on 25/8/2007.

[2] Valila, T., Kozluk T. and Mehrotra A., "Roads on downhill? Trends in EU infrastructure investment", European Investment Bank Papers, 10.1: 18-38 (2005).

[3] Laan, G. van der, Rusy, P. and Talman, D., "Optimal Provision of Infrastructure Using Public-Private Partnership Contracts: Prerequisites for Prime Performance", Centre for Economic Research (2001).

[4] Kevin, L., "Smart Contracting for Local Government Services: Processes and Experiences", Privatizing Government. London (1999).

[5] Thomson, C., "Private-public partnership: prerequisites for prime performance", European Investment Bank Papers, 10.2: 112-136 (2005).

[6] Ministry of Municipal Affairs, "Public Private Partnership, A Guide for Local Government", Official Report, British Colombia, Canada (1999).

[7] Leahy, P., "Lessons from private finance initiative in the United Kingdom", European Investment Bank Papers, 10.2: 58-70 (2005). 
[8] Monteiro, R. S., "Public-private partnership: some lessons from Portugal", European Investment Bank Papers, 10.2:.72-81 (2005).

[9] Brenk, A., Beckers, T., Heinrick, M. and Von Herschhausen, C., "Public-private partnership in EU member countries of Central and Eastern Europe: an economic analysis with case studies from highway sector", European Investment Bank Papers, 10.1:82-111 (2005).

[10] Riess, A., "Is the PPP model applicable across sectors?" European Investment Bank Papers, 10.2: 10-30 (2005).

[11] Bennett, J. and Iossa, E., "Contracting out public service provision to Not-for-profit firms", Centre for Market and Public Organization, University of Bristol, Working Paper No. 05/124 (2005).

[12] Bennett, E., Grohmann, P. and Gentry, B., "Public- private partnerships for the urban environment: options and issues", UNDP and Yale University, PPPUE Working Paper Series, Volume 1 (1999).

[13] Valila, T., "How expensive are cost savings on the economics of public-private partnership?" European Investment Bank Papers, 10.1: 94-119 (2005).

[14] Office of the Deputy Prime Minister, "Strategic Partnering Taskforce, Rethinking Service Delivery", Public / Public Partnerships, Volume 3, London (2004).

[15] Ministry of Planning, "Seventh Development Plan", Riyadh (1999).

[16] Ministry of Municipal and Rural Affairs, "Circular No. 58166/100b, Dated 15/11/1423 H.", (2003).

[17] Ministry of Municipal and Rural Affairs, "Law of Municipalities and Villages". Full version of the Law is published on: www.momra.gov.sa (1977).

[18] Abdulaal, W. A., "Framework for enterprise GIS for Saudi municipalities", International Journal for Geographical Information Science, (2008), (Forthcoming).

[19] Municipality of Jeddah, "Budget Report for 2005", Unpublished (2005).

[20] Ministry of Municipal and Rural Affairs, "Statistics of MOMRA", published on www.momra.gov.sa/specs/privoool, in 5/3/2007.

[21] Municipality of Jeddah, "Structure Plan", Unpublished (2005).

[22] Municipality of Jeddah, "Report on Cleansing Conditions", Deputy Municipality for Services, Unpublished (2003).

[23] Municipality of Jeddah, "Online; Residents' Opinion on Jeddah, Published on: www.jeddah.gov.sa, in 5/32007."

[24] Municipality of Jeddah, "Report of the General Directorate of Markets", Unpublished (2004). 


\title{
إمكانات المشناركة بين القطاع الخاص والبلديات في المملكة العربية السعودية
}

\author{
وليد عبدالله عبدالعال \\ قسم التخطبط الحضري والإقلبيهي، كلية تصامبم البيئة، جامعة الملك عبدالعزبز \\ جلة- المملكة العربية السعودية \\ (قدم للنشر:
}

المستخلص. تقدم المشـاركة بـين القطـاعين العـام والخـاص طريقـة

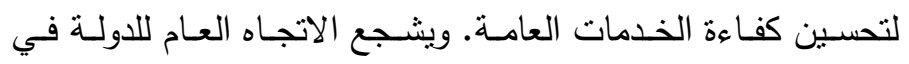

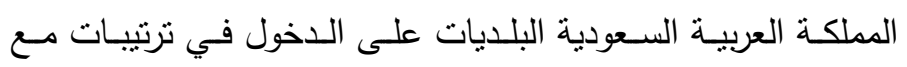
القطاع الخاص لتحسين خدماتها، ولكن التطبيقات الحالية مختصرة

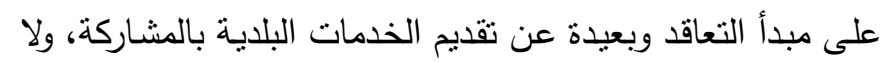
توجد محساولات جـادة للدخول في علاقات تشـاركية بين البلديات

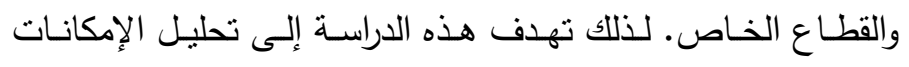

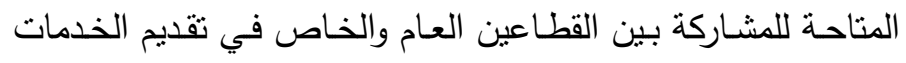

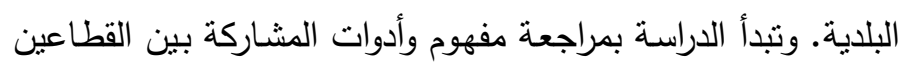
العام والخاص ومجالات تطبيقها لتكوين إطار عام لدراسـة مشاركة

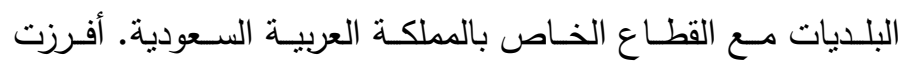

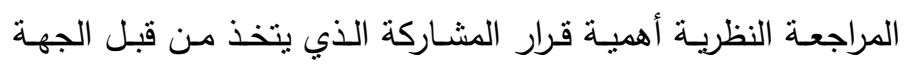

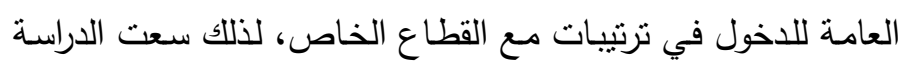

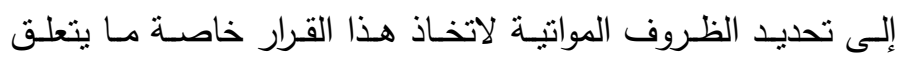
بالبلديات في المملكة العربية السعودية. وقد تم الرجوع إلى مدينة جدة

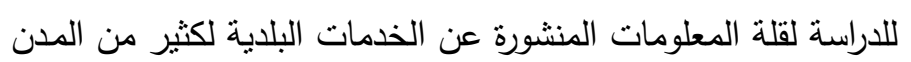




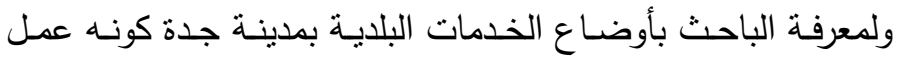

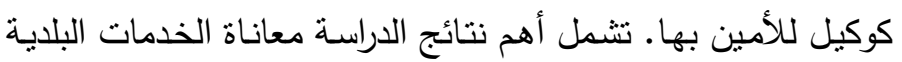

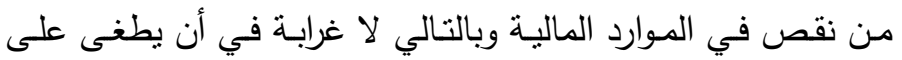

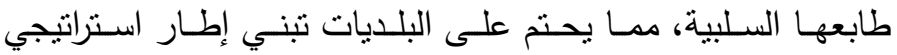

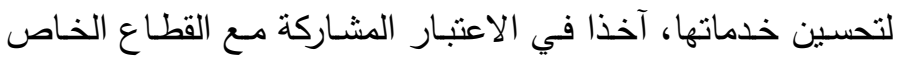
للتظلب على قلة الموارد المالية وتحسين أداء وتقديم الخدمات البلدية.

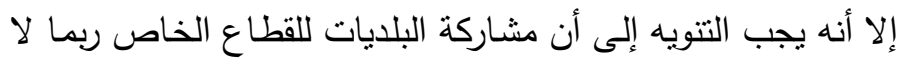

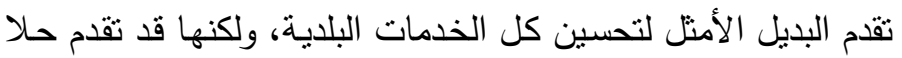
اللمشاريع الإنشائية والتي تنفذ بطرق التعاقد النمطية. كلمات مفتاحية: مشاركة القطاعين العام والخاص، الخدمات البلدية، إدارة الددن، المملكة العربية السعودية. 